\title{
Potential therapeutic options for COVID-19: an update on current evidence
}

\author{
Zahra Niknam ${ }^{1 \dagger}$, Ameneh Jafari ${ }^{2 \dagger}$, Ali Golchin ${ }^{3}$, Fahima Danesh Pouya ${ }^{4}$, Mohadeseh Nemati ${ }^{4}$, \\ Mostafa Rezaei-Tavirani ${ }^{5^{*}}$ (1) and Yousef Rasmi ${ }^{4,6^{*}}$
}

\begin{abstract}
SARS-CoV-2, a novel coronavirus, is the agent responsible for the COVID-19 pandemic and is a major public health concern nowadays. The rapid and global spread of this coronavirus leads to an increase in hospitalizations and thousands of deaths in many countries. To date, great efforts have been made worldwide for the efficient management of this crisis, but there is still no effective and specific treatment for COVID-19. The primary therapies to treat the disease are antivirals, anti-inflammatories and respiratory therapy. In addition, antibody therapies currently have been a many active and essential part of SARS-CoV-2 infection treatment. Ongoing trials are proposed different therapeutic options including various drugs, convalescent plasma therapy, monoclonal antibodies, immunoglobulin therapy, and cell therapy. The present study summarized current evidence of these therapeutic approaches to assess their efficacy and safety for COVID-19 treatment. We tried to provide comprehensive information about the available potential therapeutic approaches against COVID-19 to support researchers and physicians in any current and future progress in treating COVID-19 patients.
\end{abstract}

Keywords: COVID-19, Repurposed drugs, Convalescent plasma, Monoclonal antibodies, Immunoglobulins, Cell therapy

\section{Introduction}

Coronaviruses, a large family of viruses, has been divided into four genera: $\alpha, \beta, \gamma$, and $\delta$. These viruses can lead to infection and illness in both animals and humans. Seven coronaviruses can infect humans worldwide, but four of them, such as 229E, NL63, OC43, and HKU1, commonly infect individuals $[1,2]$. They generally lead to diseases ranging from the common cold to severe infectious respiratory illnesses, such as the most recently appeared coronavirus disease 2019 (COVID-19), leads to

\footnotetext{
*Correspondence: tavirany@yahoo.com; tavirani@sbmu.ac.ir; yrasmi@gmail. com

†Zahra Niknam and Ameneh Jafari contributed equally to the work

${ }^{4}$ Department of Biochemistry, School of Medicine, Urmia University of Medical Sciences, Urmia, Iran

${ }^{5}$ Proteomics Research Center, Faculty of Paramedical Sciences, Shahid Beheshti University of Medical Sciences, Tehran, Iran

Full list of author information is available at the end of the article
}

thousands of deaths in many countries around the world [3]. Patients infected with SARS-CoV-2 generally have major clinical symptoms and signs, such as fever, dyspnea and cough $[4,5]$. In addition, minor symptoms, such as dysgeusia, anosmia, gastrointestinal symptoms, headache and skin lesions were increasingly reported in COVID-19 patients [4-6]. This novel coronavirus, which belongs to the $\beta$ coronaviruses family, can lead to serious disorders, such as chronic lung disease, acute respiratory distress syndrome (ARDS), cardiac and renal injury, especially in patients with older age and comorbidities (diabetes mellitus, hypertension, and heart failure) [7]. Severe acute respiratory syndrome coronavirus-2 (SARS-CoV-2) begins its infection through the priming of spike (S) protein by transmembrane protease serine 2 (TMPRSS2) on the host cell membrane and interaction of S protein with angiotensin-converting enzyme 2 (ACE2) receptors $[8,9]$. The virus-cell interactions and the rapid viral replications original author(s) and the source, provide a link to the Creative Commons licence, and indicate if changes were made. The images or other third party material in this article are included in the article's Creative Commons licence, unless indicated otherwise in a credit line to the material. If material is not included in the article's Creative Commons licence and your intended use is not permitted by statutory regulation or exceeds the permitted use, you will need to obtain permission directly from the copyright holder. To view a copy of this licence, visit http://creativecommons.org/licenses/by/4.0/. The Creative Commons Public Domain Dedication waiver (http://creativeco mmons.org/publicdomain/zero/1.0/) applies to the data made available in this article, unless otherwise stated in a credit line to the data. 
stimulate the production of various pro-inflammatory cytokines and chemokines, lead to immunopathogenesis $[10,11]$.

In general, SARS-CoV-2-infected persons can be divided into three groups: (I) asymptomatic cases with or without detectable virus, (II) non-severe or mild symptomatic cases with the presence of the virus that usually recover, and (III) severe respiratory symptomatic patients with more viral load, multi-organ failure, and primarily respiratory failure that require hospitalization $[7,12]$. Based on the evidence, most COVID-19 patients have a mild or moderate infection, but up to $5-10 \%$ have a sever and even life-threatening disease course [13]. Therefore, it is necessary to find strategies for control of SARSCoV-2. In this regard, the COVID-19 vaccine program continues to be implemented globally; however, effective treatments still need to be identified, especially in countries, where vaccination is slow, and mutations can potentially threaten vaccine escape. In addition, some people may not respond fully to COVID-19 vaccines, such as patients on chemotherapy, patients with hematologic malignancies, immunocompromised people, and others. From the onset of COVID-19 until now, various studies and clinical trials have been conducted to develop a treatment against the disease, but most are yet in the early stages of research.

In this review, the current evidence of potential therapeutic options for COVID-19, including antivirals, anti-inflammatories, convalescent plasma therapy, monoclonal antibodies, immunoglobulin therapy, cell therapy, and nutraceutical supplementation will be discussed. Our aim is to assist scientists and physicians engaged in this ongoing pandemic to improve and develop their plans for further research and therapeutic management.

\section{Treatment strategies for COVID-19}

\section{Potentially recommended drugs}

Nowadays, due to the urgent need to overcome the SARS-CoV-2 pandemic, extensive global researches are underway to find appropriate drug agents to treat COVID-19. As developing a novel drug is a lengthy, expensive and risky process, to discover a cure for this pandemic, the emergency of the pandemic considered to first attempts to identify possible treatments between approved or marketed drugs. Drug repurposing is the best approach to recognize therapeutic options for COVID-19 in a limited time [14, 15]. The great benefit of this approach is the available science about the metabolic profile of drugs, dosages requirement, possible risks, complications and side effects. The drawback of these classes of medicines is their inadequate selectivity and, mostly, weak utility among families of viruses [15].
Various drugs applied in interventional clinical trials launched by the World Health Organization (WHO) can be classified according to their nature and complementary effect. Therefore, antivirals, anti-inflammatory, anticoagulants, and some common drugs together with combination therapies are used on ongoing investigations for inhibition, treatment, or supportive care. Here we discussed an updated list of the most commonly used drugs in COVID-19 treatment.

Remdesivir is the first drug that recently received Food and Drug Administration (FDA) emergency use authorization to treat SARS-CoV-2. Remdesivir, an RNAdependent RNA polymerase (RdRp) inhibitor, has shown inhibitory effects on SARS-CoV-2, both in vitro and in vivo [16]. Nowadays, remdesivir has been widely used, and many clinical trials are underway to evaluate its efficacy on COVID-19. In some studies, an improved clinical result was observed, but also multiple adverse effects in the remdesivir-treated group were occurred [17, 18]. Moreover, contrasting results have been reported in different nations owing to the small number of randomized clinical trials, varied study designs, genetic reasons and different treatment regimens (5 or 10 days) [19]. The recommended regiment for remdesivir is $200 \mathrm{mg}$ IV once, then remdesivir $100 \mathrm{mg}$ IV once daily for 4 days. However, if there is no substantial clinical improvement by day 5 , treatment may be extended to 10 days. In patients with moderate COVID-19 who do not require supplemental oxygen, there is insufficient evidence to recommend either for or against the routine use of remdesivir, but use may be appropriate in patients at high risk of disease progression. Some meta-analysis of clinical trials concluded that remdesivir has shown in little to no mortality benefit, but probably improves the clinical output and decreases serious adverse events of hospitalized patients with COVID-19. In addition, it may lead to a small reduction in the proportion receiving ventilation and higher rates of hospital discharge [19-21]. Based on CDC's guideline, in hospitalized patients who need supplemental oxygen (but without any device and ventilator), remdesivir or dexamethasone plus remdesivir is recommended. One recent clinical study has revealed that combination therapy of remdesivir plus baricitinib as a Janus kinase inhibitor, has superior effects compared to remdesivir alone in decreasing recovery time and accelerating improvement in clinical status between patients with COVID-19, considerably between those receiving high-flow oxygen or noninvasive ventilation [22]. In addition, fewer serious adverse events were observed in this combination therapy. Then in November 2021, the FDA issued an emergency use authorization for the baricitinib/remdesivir combination therapy for treatment on 
hospitalized COVID-19 patients who require supplemental oxygen.

Baricitinib on July 29, 2021, received FDA's emergency use authorization for apply in hospitalized patients who require supplemental oxygen. Baricitinib is a suppressor of the JAK-STAT pathway, which is used for preventing pro-inflammatory cytokine release and systemic inflammation in interferonopathies. Baricitinib also is a numbassociated kinase (NAK) inhibitor, with an especially high affinity for AP2-associated protein kinase 1 (AAK1) a main member of the NAK family. AAK1 binds to clathrin and phosphorylates the medium subunit of AP2 (adaptor protein 2), playing an essential role in regulating clathrin-mediated endocytosis and its suppression was indicated to decrease the infectivity of a large number of viruses. An artificial intelligence method identified the NAK family members as potential therapeutic targets against SARS-CoV-2 [23, 24]. Therefore, baricitinib may have both antiviral and anti-inflammatory properties in COVID-19. According to the new National Institutes of Health (NIH) guidelines, using baricitinib in combination with remdesivir was recommended. However, blockage of JAK-STAT pathway leads to inhibition of IFN production which may cause impairment of anti-viral immunity [25]. Currently, 20 clinical trials are ongoing for evaluating baricitinib effect on COVID-19. In hospitalized patients who have rapidly increasing oxygen needs, require high-flow oxygen or noninvasive ventilation, and have increased markers of inflammation, adding either baricitinib or IV tocilizumab to one of two therapeutic options (dexamethasone or dexamethasone plus remdesivir) is recommended. A meta-analysis of clinical trials involving a total of 2367 participants investigated the safety and efficacy of JAK-inhibitors including baricitinib and ruxolitinib in COVID-19 patients [26]. The results showed that JAK-inhibitors reduced needing invasive mechanical ventilation and had a borderline effect on rates of transferring to ICU and on ARDS. JAK-inhibitors did not reduce the time of hospitalization. The duration of JAK-inhibitor treatment of COVID-19 may be the main factor in determining its efficacy [26].

Dexamethasone is a corticosteroid used as an antiinflammatory drug and is very promising in the treatment of COVID-19. Dexamethasone leads to a decrease in mortality rates, especially in seriously ill patients (on ventilator support or needing oxygen therapy). One study entered 2104 patients who received a dose of $6 \mathrm{mg}$ per day for 10 days compared to the standard of care in 4321 patients. The risk of death was decreased by one-third in the dexamethasone arm in ventilated patients [27]. The results of the several clinical trials led to the wide application of dexamethasone for patients on a ventilator or receiving supplemental oxygen. According to literatures, corticosteroids were associated with reduced all-cause mortality [28, 29]. Using corticosteroids in severe COVID-19 patients reduced the occurrence of composite disease progression, but not enhanced the incidence of serious adverse events [28]. According to CDC recommendations, the dosing regimen for dexamethasone is $6 \mathrm{mg}$ IV or oral once daily for up to 10 days or until hospital discharge. Moreover, if dexamethasone is not available, alternative glucocorticoids such as prednisone $(40 \mathrm{mg})$, methylprednisolone $(32 \mathrm{mg})$, or hydrocortisone $(160 \mathrm{mg}$ ) can be used.

Heparin as an anticoagulant agent has been used in COVID-19 patients from prophylactic to therapeutic doses for preventing the formation of blood clots [30]. During SARS-CoV-2 infection, the alveolar damage and the pulmonary microvascular thrombosis due to the direct viral infection of endothelial cells are the major causes of acute lung injury [30, 31]. Hence, COVID19-associated coagulopathy is occurred due to activation of the immune system and thromboinflammatory responses and endotheliopathy [31]. Histopathological studies demonstrated that endotheliitis with diffuse endothelial inflammation and microvascular and macrovascular thrombosis occur in the venous and arterial circulations leading to multiorgan dysfunction and thrombotic complications in COVID-19 [30, 31]. A recent randomized controlled trial indicated that the use of therapeutic-dose anticoagulation with heparin compared to usual-care thromboprophylaxis in noncritically ill COVID-19 patients enhanced the probability of survival to hospital discharge with decreased use of cardiovascular or respiratory organ support [32]. For COVID-19 patients admitted to the ICU, the results of another randomized trial do not support the routine empirical use of intermediate-dose prophylactic anticoagulation [33]. In a retrospective study, early heparin treatment indicated lower mortality risk in patients with COVID-19 [4]. According to the last update of COVID-19 treatment guidelines (February 11, 2021) (https://www.covid19treatmentguidelines.nih.gov/), anticoagulants and antiplatelet therapy should not be used for nonhospitalized COVID-19 patients. However, nonpregnant hospitalized adults with COVID-19 should receive prophylactic dose anticoagulation. At present, there is inadequate data to recommend either for or against the use of thrombolytics or higher than the prophylactic dose of anticoagulation for the prevention of venous thromboembolism in hospitalized COVID-19 patients.

Some repurposed drugs under evaluation in clinical trials for the treatment of COVID-19 are described in Table 1. 
Table 1 Summarizes of potential drugs under investigation in clinical trials against COVID-19

\begin{tabular}{|c|c|c|c|c|}
\hline Drugs & Drug target & Related disease & Results of studies & References \\
\hline \multicolumn{5}{|l|}{ Antivirals } \\
\hline Favipiravir & RdRp inhibitor & Influenza & $\begin{array}{l}\text { Clinical improvement and viral clearance } \\
\text { within } 7 \text { or } 14 \text { days, lower needing to sup- } \\
\text { plemental oxygen therapy }\end{array}$ & [34-36] \\
\hline Sofosbuvir/daclatasvir & Nucleoside analog/NS5A inhibitor & $\mathrm{HCV}$ & $\begin{array}{l}\text { Improving clinical outcomes, reduce mor- } \\
\text { tality rate and need for ICU/IMV }\end{array}$ & {$[37,38]$} \\
\hline Molnupiravir & RNA mutagenesis & Influenza & $\begin{array}{l}\text { Highly effective at reducing nasopharyn- } \\
\text { geal SARS-CoV-2 infectious virus and viral } \\
\text { RNA, has a favorable safety and tolerability } \\
\text { profile }\end{array}$ & [39] \\
\hline Danoprevir & NS3/4A protease inhibitor & $\mathrm{HCV}$ & $\begin{array}{l}\text { Significantly shorter mean time to achieve } \\
\text { both negative nucleic acid testing and } \\
\text { hospital stays }\end{array}$ & {$[40]$} \\
\hline \multicolumn{5}{|l|}{ Anti-inflammatory drugs } \\
\hline Ruxolitinib & JAK inhibition & Rheumatoid arthritis & $\begin{array}{l}\text { Faster clinical improvement, significant } \\
\text { chest CT improvement }\end{array}$ & {$[41,42]$} \\
\hline Tofacitinib & JAK inhibition & Rheumatoid arthritis & $\begin{array}{l}\text { Lower risk of death or respiratory failure } \\
\text { through day } 28\end{array}$ & {$[43]$} \\
\hline Imatinib & JAK inhibition & Cancer & $\begin{array}{l}\text { Beneficial effects on survival and duration } \\
\text { of mechanical ventilation }\end{array}$ & [44] \\
\hline Fluvoxamine & Agonist for the sigma-1 receptor & Anti-depressant & $\begin{array}{l}\text { Lower likelihood of clinical deterioration } \\
\text { over } 15 \text { days }\end{array}$ & [45] \\
\hline Methylprednisolone & $\begin{array}{l}\text { Inhibition of proinflammatory cytokine } \\
\text { production }\end{array}$ & $\begin{array}{l}\text { Inflammation, } \\
\text { immune system } \\
\text { disorders }\end{array}$ & $\begin{array}{l}\text { Decreased the recovery time, the need for } \\
\text { transfer to intensive care and the severity } \\
\text { markers C-reactive protein, D-dimer and } \\
\text { LDH, lower need for a ventilator }\end{array}$ & {$[46-48]$} \\
\hline Budesonide & $\begin{array}{l}\text { Inhibition of proinflammatory cytokine } \\
\text { production }\end{array}$ & Asthma & $\begin{array}{l}\text { Reduced the likelihood of needing urgent } \\
\text { medical care and reduced time to recov- } \\
\text { ery, reduced hospital admissions or deaths }\end{array}$ & {$[49,50]$} \\
\hline Artesunate & $\begin{array}{l}\text { NF-kB-coronavirus effect and chloroquine- } \\
\text { like endocytosis inhibition }\end{array}$ & Malaria & $\begin{array}{l}\text { Lower treatment time, improve prognosis } \\
\text { and eliminate pathogens, with fewer } \\
\text { adverse reactions }\end{array}$ & [51] \\
\hline Type I interferons & $\begin{array}{l}\text { Balances the expression of pro- and anti- } \\
\text { inflammatory agents }\end{array}$ & Multiple sclerosis & $\begin{array}{l}\text { Decreased mortality rate and time of } \\
\text { hospitalization }\end{array}$ & {$[52,53]$} \\
\hline \multicolumn{5}{|l|}{ Other most common drugs } \\
\hline Telmisartan & Angiotensin receptor blocker & Hypertension & $\begin{array}{l}\text { Safe and reduced morbidity and mortality } \\
\text { in hospitalized patients, anti-inflammatory } \\
\text { effects }\end{array}$ & {$[54,55]$} \\
\hline Nitazoxanide & $\begin{array}{l}\text { Inhibition of the pyruvate: ferredoxin/flavo- } \\
\text { doxin oxidoreductase cycle }\end{array}$ & Anti-parasitic & $\begin{array}{l}\text { Improvement in clinical, virologic and } \\
\text { inflammatory outcomes in moderate } \\
\text { COVID-19, safe and significantly reduced } \\
\text { viral load in early use }\end{array}$ & {$[56,57]$} \\
\hline Niclosamide & $\begin{array}{l}\text { Prevention of viral entry by altering endo- } \\
\text { somal pH, Prevention of viral replication by } \\
\text { inhibition of autophagy }\end{array}$ & Anti-parasitic & $\begin{array}{l}\text { Accelerated time to recovery about } 3 \text { to } \\
5 \text { days in moderate to severe COVID-19 } \\
\text { patients especially those with co-mor- } \\
\text { bidities }\end{array}$ & [58] \\
\hline Bromhexine & TMPRSS2 protease blocker & Mucolytic & $\begin{array}{l}\text { The early administration reduced the ICU } \\
\text { transfer, intubation, and the mortality rate }\end{array}$ & {$[59,60]$} \\
\hline Dornase alfa & Recombinant human deoxyribonuclease I & Cystic fibrosis & $\begin{array}{l}\text { Improvement in oxygenation, reduction in } \\
\text { ventilatory support }\end{array}$ & {$[61,62]$} \\
\hline Dexmedetomidine & Selective alpha-2 adrenoceptor agonist & Sedation & $\begin{array}{l}\text { Effective sedative and may improve } \\
\text { oxygenation, significantly reduced the } \\
\text { intubation rate and ICU length of stay by } \\
2.9 \text { days, did not change the mortality rate } \\
\text { decline in heart rate and high incidence of } \\
\text { bradycardia and hypotension }\end{array}$ & {$[63,64]$} \\
\hline Fluoxetine & Selective serotonin reuptake inhibitor & Antidepressant & $\begin{array}{l}\text { Lower risk of death or intubation in hospi- } \\
\text { talized patients }\end{array}$ & [65] \\
\hline
\end{tabular}




\section{Antibody-based immunotherapeutic strategies}

Based on exiting evidence and previous experience in treating other viral infections, antibody-based treatments as a kind of passive immunotherapy may be appropriate to achieve COVID-19 treatment [66]. In this section, immunotherapy based on the antibody include neutralizing monoclonal antibodies, and intravenous immunoglobulins as effective strategies for clinical treatment of SARS-CoV-2 infection have been discussed.

\section{Convalescent plasma therapy}

Convalescent plasma (CP) therapy includes injection of plasma from recovered patients to people who are yet infected. CP can prevent the infection progression and reverse the inflammatory process through several mechanisms. The present neutralizing antibodies (NAbs), immune-modulatory cytokines and autoantibodies in convalescent plasma mediate its therapeutic effects. An antibody may bind to the virus, thereby directly neutralizing its infectivity, also other pathways mediated by antibody, like complement activation, phagocytosis and/ or antibody-dependent cellular cytotoxicity can also contribute to its therapeutic effect $[67,68]$. During apheresis, in addition to NAbs, other proteins such as natural antibodies, anti-inflammatory cytokines, clotting factors, and other undefined proteins are collected from donors
[69]. In this sense, CP transfusion in infected patients can provide additional benefits, such as immunomodulation, by improving the severity of the inflammatory response. The stages of convalescent plasma therapy are illustrated in Fig. 1.

More than 1 year since the pandemic began, there are several reports of application of $\mathrm{CP}$ in the treatment of patients with SARS-CoV-2 infection. However, the benefit of this approach remains controversial. The results of a study to evaluate the effect of $\mathrm{CP}$ on mortality between patients with COVID-19 showed that patients with SARS-CoV-2 infection administered with $\mathrm{CP}$ (within 3 days of hospital admission) indicated a lower mortality rate compared with patients receiving standard care [70]. The data of another research demonstrated uncertain estimates on the effectiveness of CP for COVID-19 [71]. There is low certainty evidence of a probable decrease in mortality and mechanical ventilation, rapid viral clearance and the absence of any significant adverse events. On the other hand, CP has significant limitations such as lack of standard dosing methods, lack of availability to sufficient donors and host interactions and adverse effects, which can limit its usage [72, 73]. Indeed, for approval of CP as a potential treatment for COVID-19, designing extensive, good quality and adequately powered randomized clinical trials is needed.

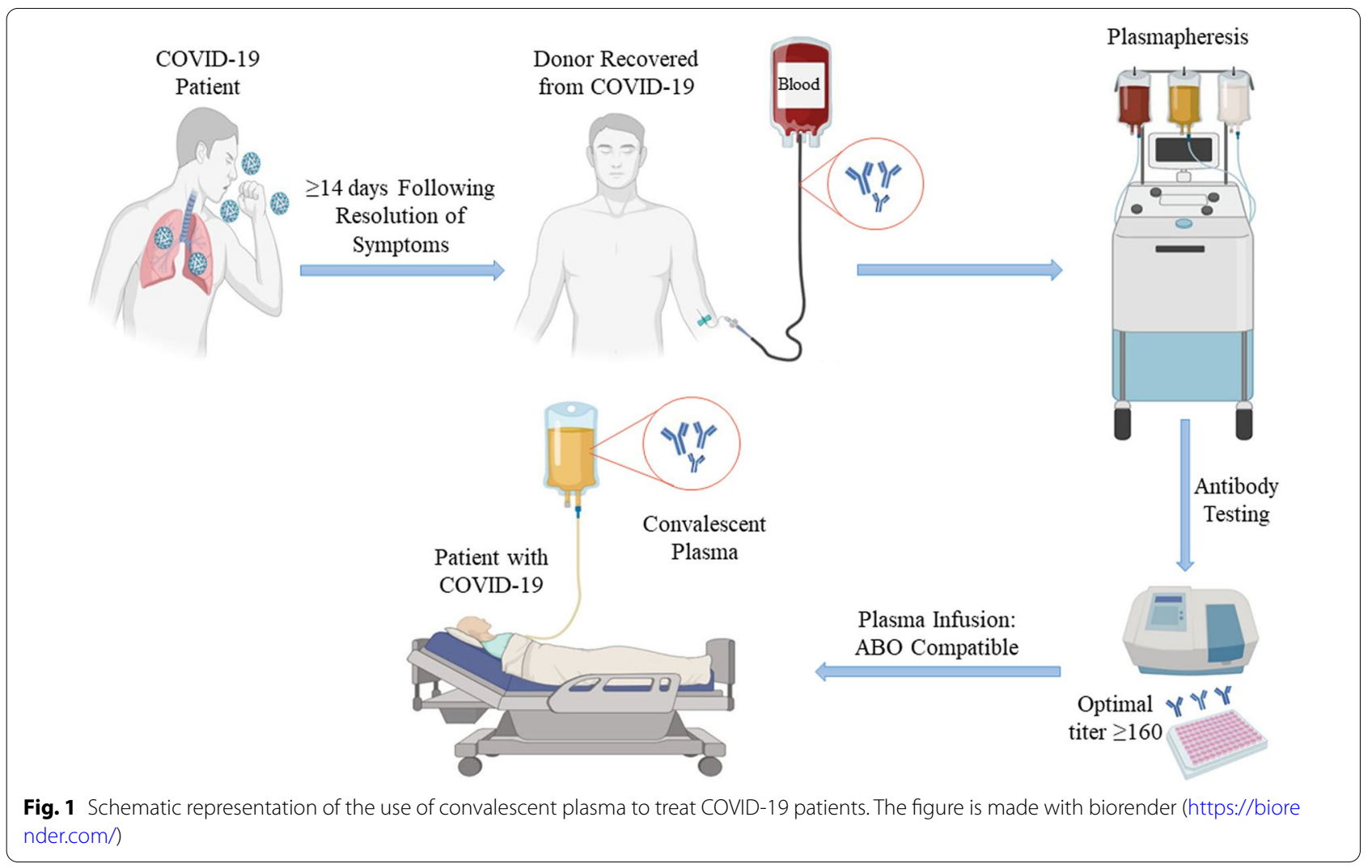




\section{Monoclonal antibody therapy}

Monoclonal antibodies (mAbs), as a novel class of antibodies, are primarily developed by a specific group of $B$ cells against a particular epitope of an antigen. mAbs therapy is a new era in the prevention of infectious disease, which can be derived from blood of the convalescent patients or engineered in the laboratory. This method can overcome many limitations in terms of specificity, safety, purity, and risk of blood-borne pathogen associated with plasma therapy and intravenous immunoglobulin preparations. The mAbs are involved in the treatment of infectious diseases by binding to a specific target. This binding is very diverse and can mimic, block or alter precise mechanisms to provide a very specific treatment for diseases with the appropriate therapeutic intervention [74].

Anti-host monoclonal antibodies SARS-CoV-2 infections due to overproduction of inflammatory cytokines and chemokines, along with disruption of innate defense mechanisms, lead to a lack of immune response regulation also cause cytokine storms. For this reason, older people and people with certain diseases, such as patients with cardiovascular disease, diabetes, and cancer, may be prone to COVID-19 due to their lack of immunity and their tendency to exaggerated inflammatory responses [75]. Currently, significant efforts have been made to assess the effectiveness of different $m A b s$ that regulate the immune system, and target the pathways of SARS-CoV-2 infection, to control the immune response and prevention of the cytokines storm in severe COVID-19 patients. In this context, monoclonal antibodies block inflammatory mediators, such as IL-1 $\beta$, IL-2, IL-6/IL-6R, TLR3, IL-8, IL-12/IL-23, IL-17, TNF $\alpha$, G-CSF, GM-CSF, ITAM (immune-receptor tyrosine-based activation motif), MCP1 $\alpha$, MIP1 $\beta$, IP-10/CXCL10 (interferon $\gamma$-inducible protein 10), and complement component-5 [76-79].

Several studies reported the elevation of IL-6 levels in patients with SARS-CoV-2 infection, which correlates with disease severity [23]. Between the excessive cytokines released by activated macrophages, IL- 6 is one of the key cytokines. IL- 6 is released in response to acute inflammation, induction of TNF- $\alpha$, lipopolysaccharides, and IL-1 [23]. The binding of IL-6 to the transmembrane or soluble form of the IL-6 receptor (IL-6R) stimulates the downstream gp130/JAK/STAT pathway [80]. Overactivation of IL-6 signaling causes numerous biological processes that help to organ damage. In many countries, the safety, efficacy, and pharmacodynamics of tocilizumab, as an IL-6 receptor-targeted mAb, have been evaluated to reduce the inflammatory response in severe COVID-19 patients. It is approved by the US FDA for the treatment of severe cytokine release syndrome during
COVID-19 [81]. A meta-analysis of randomized clinical trials showed that tocilizumab was associated with a lower mortality rate in COVID-19 prospective studies [82]. The CDC panel recommends using tocilizumab (single IV dose of tocilizumab $8 \mathrm{mg} / \mathrm{kg}$ actual body weight up to $800 \mathrm{mg}$ ) in combination with dexamethasone [6 $\mathrm{mg}$ daily for up to 10 days] in certain hospitalized patients who are exhibiting rapid respiratory decompensation due to COVID-19.

IL-1 $\beta$ plays an important role in the cytokine storm associated with COVID-19 infection [76]. Anakinra is a recombinant, non-glycosylated human IL-1 receptor antagonist, which has a highly safe profile and large dosages have been utilized even in patients with severe viral illnesses, such as EBV, H1N1, and Ebola [83]. A recent cohort study investigated the anakinra effect on hyperinflammatory state, in SARS-CoV-2-infected patients. It was reported that anakinra significantly decreased both the requirement for invasive mechanical ventilation in the intensive care unit (ICU) and mortality between patients with severe SARS-CoV-2 infection, without substantial adverse effects. Up to this date, there are 38 ongoing clinical trials that investigate the use of anakinra as a promising treatment for SARS-CoV-2 infection [24]. A systematic review and patient-level meta-analysis demonstrated that anakinra could be a safe and antiinflammatory medication to decrease the mortality rate in moderate to severe COVID-19 hospitalized patients, especially in the existence of signs of hyper inflammation, such as C-reactive protein concentrations higher than $100 \mathrm{mg} / \mathrm{L}$ [84]. In addition, another meta-analysis concluded that administration of anakinra in COVID-19 patients decreases both the requirement for mechanical ventilation and mortality rate of hospitalized non-intubated COVID-19 patients without higher serious adverse events [85]. However, more investigations are needed to the approval of anakinra as a potential treatment for COVID-19.

IL-17 operates 'upstream' of both IL-1 and IL-6, so it has been suggested that IL-17 can be involved in hyperinflammatory syndrome in COVID-19. A phase 2 clinical trial (NCT04403243) on secukinumab, the IL-17-specific $\mathrm{mAb}$, is currently underway. One trial showed that administration of netakimab as an anti-IL-17 mAb in patients with severe COVID-19 was related to clinically significant improvements, reduction of inflammatory biomarkers, and an improvement in oxygenation levels without significant adverse events [86]. However, this drug does not affect requiring mechanical ventilation and mortality.

GM-CSF (granulocyte-macrophage colony-stimulating factor), an important proinflammatory cytokine, plays an essential role in the immunopathogenesis of 
COVID-19 [87]. Hence, anti-GM-CSF therapy has been used to hospitalized severe COVID-19 patients, and clinical trials have indicated the efficacy of GM-CSF blockade for COVID-19 [87]. In the announced clinical trials, GM-CSF mAbs, including mavrilimumab, lenzilumab, and tocilizumab have been used in the treatment of SARS-CoV-2-infected patients [88]. A meta-analysis of GM-CSF antibody therapy for COVID-19 patients was performed, and a total of 12 qualified studies with 8979 [experimental group $(n=2673)$ and control group $(n=6306)]$ COVID-19 patients were included [88]. The results showed that the GM-CSF antibody therapy was associated with a $23 \%$ reduction in mortality rate. GMCSF mAbs showed no effect on improving ventilation in COVID-19 patients and secondary infection. Overall, they concluded that GM-CSF antibodies can reduce respiratory symptoms and can be beneficial for severe COVID-19 patients [88]. However, the safety and efficacy of GM-CSF mAbs in the treatment of SARS-CoV2 -infected patients are controversial and more random clinical trials are required to evaluate these therapeutics in COVID-19.

A brief description of mAbs currently in development for COVID-19 is given in Table 2.

Anti-virus monoclonal antibodies Currently, major research has focused on the exploring of mAbs that target the pathogen protein. The S protein presents on the sur- face of coronavirus and plays a vital role in virus entry and inducing host immune responses [89]. Prior studies have recognized a variety of effective $m A b s$ to prevent the virus from entering host cells by targeting the SARS-CoV S protein. Depending on the site of binding, the antibodies that bind to the $S$ protein can inhibit conformational change of the $S$ protein and block membrane fusion or block its interaction with ACE2. Hence, the $S$ protein could be considered as a key target to develop effective $\mathrm{mAb}$ against SARS-CoV-2. The critical target of $\mathrm{mAbs}$ is RBD (residues 318-510) of the S protein [90].

The FDA has currently issued emergency use authorizations for eight anti-SARS-CoV-2 monoclonal antibody products to treat mild to moderate COVID-19 in nonhospitalized patients with laboratory-confirmed SARS$\mathrm{CoV}-2$ infection who are at high risk of progressing to severe disease and/or hospitalization. These clinical use $\mathrm{mAbs}$ are include: bamlanivimab and etesevimab (from Eli Lilly); cilgavimab and tixagevimab (from AstraZeneca); casirivimab and Imdevimab (from Regeneron); regdanvimab (from Celltrion); and sotrovimab (from GSK and Vir Biotechnology) [91].

These therapeutic mAbs have indicated high effectiveness in trial studies with a decrease of $70-85 \%$ in hospitalization or death. Furthermore, 2B04 and 47D11 from AbbVie; BRII-196 and BRII-198 from Brii Biosciences; and TY027 from Tychan are under Phase III trials [91]. Given the emergence of different SARS-CoV-2 variants

Table 2 Neutralizing monoclonal antibodies under investigation in clinical trials against COVID-19

\begin{tabular}{|c|c|c|c|}
\hline Target & Name & Related disease & Trial ID \\
\hline \multirow[t]{3}{*}{ IL-6 receptor } & Tocilizumab & Rheumatoid arthritis & NCT04730323 \\
\hline & Sarilumab & Rheumatoid arthritis & NCT04315298 \\
\hline & Levilimab & Rheumatoid arthritis & NCT04397562 \\
\hline \multirow[t]{4}{*}{ IL-6 } & Siltuximab & Rheumatoid arthritis & NCT04329650 \\
\hline & Clazakizumab & Rheumatoid arthritis & NCT04494724 \\
\hline & Sirukumab & Rheumatoid arthritis & NCT04380961 \\
\hline & Olokizumab & Rheumatoid arthritis & NCT04380519 \\
\hline IL-1 receptor & Anakinra & Rheumatoid arthritis & NCT04366232 \\
\hline IL1 $\beta$ & Canakinumab & systemic juvenile idiopathic arthritis and active Still's disease & NCT04362813 \\
\hline GM-CSF receptor & Mavrilimumab & Rheumatoid arthritis & NCT04447469 \\
\hline \multirow[t]{4}{*}{ GM-CSF } & Lenzilumab & Chronic myelomonocytic leukemia, juvenile myelomonocytic leukemia & NCT04583969 \\
\hline & Gimsilumab & Rheumatoid arthritis, multiple sclerosis, asthma, cancer & NCT04351243 \\
\hline & Otilimab & Rheumatoid arthritis & NCT04376684 \\
\hline & TJ003234 & Rheumatoid arthritis, cytokine release syndrome, osteoarthritis & NCT04341116 \\
\hline IFN- $\gamma$ & Emapalumab & Hemophagocytic lymphohistiocytosis & NCT04324021 \\
\hline \multirow[t]{2}{*}{ TNF-a } & Adalimumab & Rheumatoid arthritis & NCT04705844 \\
\hline & Infliximab & Autoimmune diseases & NCT04425538 \\
\hline \multirow[t]{2}{*}{ IL-17 } & Secukinumab & Psoriasis, ankylosing spondylitis, psoriatic arthritis & NCT04403243 \\
\hline & Ixekizumab & Autoimmune diseases & NCT04724629 \\
\hline IL-12/IL-23 & Risankizumab & Moderate to severe plaque psoriasis & NCT04583956 \\
\hline
\end{tabular}


in various parts of the world, it was reported that RBDspecific NAbs are variably effective against these variants.

According to last update CDC's COVID-19 guideline (September 29, 2021) (https://www.covid19treatmen tguidelines.nih.gov/), in people with mild to moderate COVID-19 who are at high risk of progressing to severe disease and/or hospitalization, the combination of bamlanivimab and etesevimab has been found to provide a therapeutic benefit. The Delta variant, which has the L452R and T478K mutations, has demonstrated susceptibility to these mAbs combination in laboratory studies [92]. Because, in recent months, the Delta variant is the predominant variant circulating in all states of the United States, bamlanivimab (700 mg) plus etesevimab (1400 mg) to be administered as an IV infusion as one of the recommended treatment options for this patient population [93]. BLAZE-2, a Phase 3, randomized, placebo-controlled trial, is currently the only clinical trial that supports the use of either of these mAbs for postexposure prophylaxis [94]. In laboratory studies, the Delta variant is also susceptible to casirivimab $(600 \mathrm{mg})$ plus imdevimab $(600 \mathrm{mg}$ ) and to sotrovimab $(500 \mathrm{mg})$, so these products continue to also be recommended for this patient population [95]. Interestingly, newly known RBD core-binding NAbs SARS2-38 and LY-CoV1404 as monotherapy strongly neutralize all SARS-CoV-2 variants [91].

The cocktail of mAbs can exhibit more efficient antivirus activity that could improve treatment efficacy and inhibit viral escape. Although this approach has promising results in infection neutralization, large-scale creation of monoclonal antibodies is costly, labor intensive, and time-consuming, especially against emerging pathogens. However, with recent advances in protein production platforms, antibody production can be made more costeffective. It is possible to clone and express the sequences of effective monoclonal antibodies in proper expression systems, such as mammals, yeasts or plants, and then recombinant monoclonal antibodies could be tested [74]. Other challenges are determining at-risk individuals who benefit most from prophylactic neutralizing mAbs, optimum timing for administration of neutralizing mAbs, duration of protection provided by these mAbs and any potential effect of mAb therapy on subsequent vaccination [96].

\section{Intravenous immunoglobulins therapy}

Intravenous immunoglobulin (IVIG) contains the natural therapeutic immunoglobulin G (IgG), is isolated from the plasma of several thousand healthy donors. It is one of the immunotherapy methods used to treat various autoimmune and inflammatory diseases. In addition to clinically confirmed pathological conditions, IVIG has been evaluated as an unlabeled drug in more than 100 diseases. IVIG uses its therapeutic benefits in autoimmune diseases via several non-specific mechanisms that target mediators of the inflammatory immune response. The latest evidence from Shao et al. and other studies suggest that early initiation and high-dose injection of IVIG therapy may be helpful in the recovery of critical ill COVID-19 patients [97].

While the its mechanisms are still not exactly understood, the decline in inflammatory mediators following IVIG treatment indicate that IVIG may be effective in cytokine storming in hospitalized COVID-19 patients through scavenging of complement and inhibition of innate immune cell activation [98]. In a recently published paper, Cheng et al. found that SARS-CoV-2 encodes a superantigen-like motif near its S1/S2 cleavage site that is not present in other SARS family coronaviruses [99]. The authors conclude that this motif may explain the unique potential of SARS-CoV-2 in causing the cytokine storm observed in COVID-19. Since IVIG has antibodies that react against SARS-CoV-2 antigens, IVIG may suppress superantigen-mediated $\mathrm{T}$ cell activation and release of cytokine [99].

Up to date, 29 clinical trials are conducted in many countries to evaluate the impact of IVIG on patients with severe SARS-CoV-2 infection. However, the advantages of IVIG treatment for COVID-19 remains controversial. Recently, a meta-analysis was performed to assay the efficacy of IVIG therapy for COVID-19 patients [100]. In this meta-analysis, four clinical trials and three cohort studies containing 825 hospitalized patients are retrieved. Their results showed that the severity of COVID-19 is associated with the efficiency of IVIG. In the group of patients with critical conditions, IVIG could decrease mortality compared with the control group.

Alternatively, due to the broad-spectrum anti-inflammatory possessions of IVIG, this treatment can be combined with IL-1 and IL-6 targeted-immunotherapies, which show promising responses to explore therapeutic effects of additive or synergistic therapy [76, 78, 98].

Nevertheless, there is insufficient evidence for the approval of this therapeutic option and its beneficial effects for COVID-19 patients.

\section{Cell therapy for COVID-19 treatment}

Currently, several cell-based therapy approaches including Mesenchymal stem cells (MSCs), Natural Killer (NK) cells, dendritic cells (DCs), engineered lymphocytes, new cell-based vaccine platforms, and Extracellular Vesicles are undergoing clinical trials to accept an approved therapeutic of COVID-19. These therapeutic approachs and their clinical application concepts for use in COVID-19 treatment are discussed below (Fig. 2). 


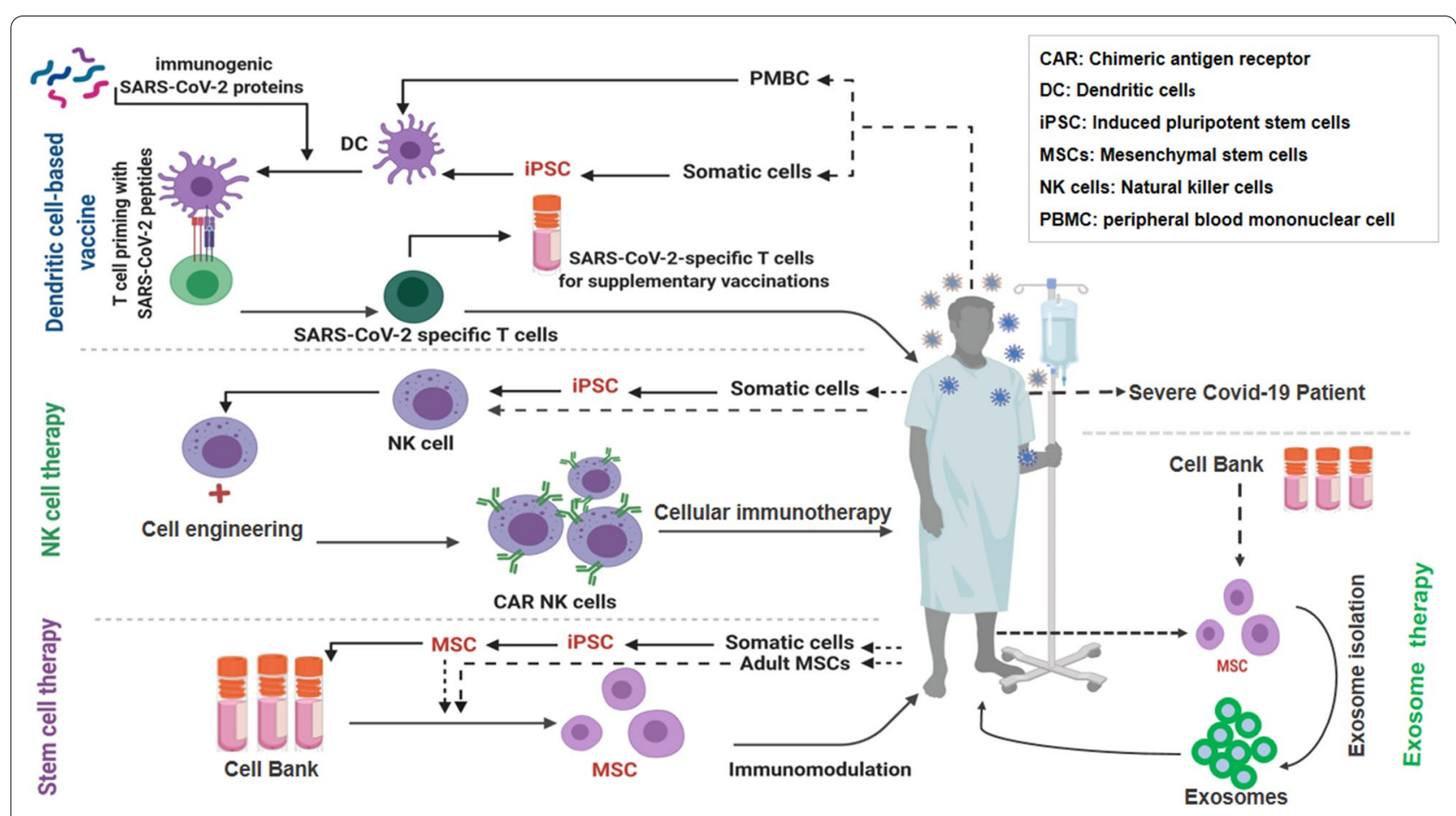

Fig. 2 Summary schematic of immune cell-based therapy, which can be used to treat COVID-19 with permission from [128]. This figure represents a strategy to produce a cell-based products to prevent and treat COVID-19 patients. The figure is made with biorender (https://biorender.com/)

\section{Stem cell-based therapy}

Soon after the COVID-19 outbreak, stem cell researchers suggested using MSCs, a suitable therapeutic candidate, to treat severe COVID-19 patients, and immediately its clinical trials were commenced. Due to migrating and homing ability, immunoregulatory and immunomodulatory function, anti-inflammatory effects, and stemness differentiation potential, it seems that MSCs could be demonstrated effects therapeutically in ARDS like severe and critical pneumonia COVID-19 [101, 102]. MSCs can be isolated from diverse adult tissues, including optionally bone marrow (BM), peripheral blood (PB) and adipose tissues (AT) (such as abdominal fat, buccal fat pad, and infrapatellar fat pad) and as well as neonatal birthassociated tissues, including placenta (PL), cord blood (CB) and umbilical cord (UC), Warton jelly (WJ), amniotic fluid (AF), and then stored for future desirable clinical applications [103-105]. It is hypothesized that MSCs could improve acute lung damage and repress the cellmediated inflammatory response caused by SARS-CoV-2 [106]. Besides, MSCs are resistant to infection, and they lack the ACE2 receptor that SARS-CoV-2 applies for viral entry into cells [107, 108]. For COVID-19 treatment, MSCs can increase the lymphocyte count and regulatory DCs to boost their antiviral property, which results in the reduced level of $\mathrm{C}$-reactive protein and pro-inflammatory cytokines (IL-6, TNF $\alpha$, IL-8, etc.). These markers are the central markers of inflammation and ROS to diminish inflammation and oxidative stress. On the other hand, MSCs can increase the level of IL-10 as an anti-inflammatory protein activating regulatory cells, such as Tregs [102, 109]. Hence, MSCs play a central role in immune homeostasis by associating with cytokines, chemokines, and cell surface molecules [109]. Conclusively, all these immunomodulatory characteristics provide considerable potential for MSCs in clinical therapies.

During the COVID-19 pandemic, several clinical studies published clinical results on MSC-based therapy for COVID-19 patients with safety results and/or without serious unfavorable effects (Table 3) [101]. Umbilical cord tissues (especially umbilical cord blood and Wharton's jelly), bone marrow, menstrual blood, and the elected MSC-derived products of companies are the primary MSC sources used in clinical trials. RemestemcelL (Cellavita Mesoblast) and NestCell ${ }^{\circledR}$ (Cellavita) are the two leading companies in introducing MSC therapy for use in COVID-19 clinical trials [101].

Wang et al. performed a systematic review and metaanalysis to evaluate the safety and effectiveness of MSCs therapy for COVID-19-infected patients [110]. Twenty two studies containing 371 patients were included in their study. Allogeneic MSCs from different sources were injected in 247 participants. The results demonstrated that MSC therapy significantly decreased the 
Table 3 List of published MSC-based clinical studies for COVID-19 treatment

\begin{tabular}{|c|c|c|c|c|}
\hline Source of MSCs & Study type and number of enrollment (N) & Country & Results & References \\
\hline Umbilical cord & Double-blind clinical trial phase 1/2a; 24 & USA & $\begin{array}{l}\text { No adverse events, decreasing IFN- } \gamma \text {, IL-6, TNF- } \\
a \text {, and GM-CSF }\end{array}$ & [111] \\
\hline Umbilical cord & Clinical trial phase 2; 101 & China & $\begin{array}{l}\text { Reducing the proportions of solid component } \\
\text { lesion volume, no adverse events }\end{array}$ & [112] \\
\hline Umbilical cord & Clinical trial phase 1;18 & China & $\begin{array}{l}\text { No adverse events, Decreasing IFN- } \gamma \text {, TNF- } a \text {, } \\
\mathrm{IL}-6 \text {, and IL-1 }\end{array}$ & [113] \\
\hline Umbilical cord & Randomized clinical trial; 41 & China & No adverse effects, decreasing CRP and IL-6 & [114] \\
\hline Umbilical cord and placental & Randomized clinical trial phase $1 ; 11$ & Iran & $\begin{array}{l}\text { No serious adverse events, decreasing TNF-a, } \\
\text { IFN- } \gamma_{\text {, IL- } 8, \text { IL-6, and CRP }}\end{array}$ & {$[115]$} \\
\hline Menstrual blood-derived MSCs & Pilot clinical trial; 2 & China & $\begin{array}{l}\text { FiO21 decreased, } \mathrm{SaO} 22 \text { and PO23 improved, } \\
\text { and adsorbing bilateral lung exudate lesions }\end{array}$ & [116] \\
\hline Menstrual blood-derived MSCs & Phase I clinical trial; 44 & China & Lower mortality, SpO2 was improved & [117] \\
\hline AT-MSC & Randomized clinical trial phase $1 ; 13$ & Spain & $\begin{array}{l}\text { No adverse events, reducing IL-6, CRP, LDH fer- } \\
\text { ritin, and D-dimer, and increasing lymphocytes }\end{array}$ & [118] \\
\hline Unknown & Pilot clinical trial; 10 & China & $\begin{array}{l}\text { No adverse events reduced CRP and TNF- } a \text {, } \\
\text { increased IL-10, normalization of immune cell } \\
\text { populations }\end{array}$ & [119] \\
\hline
\end{tabular}

occurrence of adverse events and mortality and the difference compared with the control group was statistically significant. No significant adverse events related to MSC therapy were observed. Pulmonary function, radiographic analysis, and inflammation- and immunity-associated biomarker levels all indicated improving trends. They concluded that MSC therapy is an effective and safe approach for the treatment of COVID-19-related pneumonia [110].

Nevertheless, there are no extensive data to estimate MSC's role for the treatment of COVID-19, and no MSCbased therapies have been approved by the FDA in this regard. Hence, more research studies and clinical trial results are needed to clarify the precise mechanism by which MSCs support COVID-19-infected patients. Several clinical studies are ongoing in this regard.

MSC therapy may be an alternative approach for treating COVID-19, notably in patients with ARDS. However, several limitations have been identified in this respect. Main limitations including in failed up-scaling of the product to large-scale supply, cost issue, and the absence of translation to efficient clinical application (e.g., cell expansion from the starting material, cell banking, cell viability problems after thawing, and suboptimal delivery route), which could account for the restrictions of these studies.

\section{Other cell-based therapies}

The next candidate for cell-based therapy for COVID19 patients is adoptive NK cells and CAR-NK cells. The NK cells are cytotoxic lymphocytes that include $10-15 \%$ of total peripheral blood white blood cells in humans. These cells have a critical role in linking during viral infection, the host cells shift to more responsive to NK cells and occur rules through: (I) upregulation of self-encoded molecules by infection or cellular stress; (II) downregulation of ligands for inhibitory receptors which suppress NK cell activation; and (III) direct identification of viral parts [120]. Recently, Novocellbio (Incheon, South Korea) reported promising results using NOVO-NK, an autologous NK cell treatment, in both conditions in vitro and in vivo. Hence, the company is leading further preclinical studies to analyze the mechanisms used by NOVO-NK therapy against SARS-CoV-2 [101]. Recently, a number of clinical trials have been conducted to investigate the safety and immunogenicity of intravenous infusion of peripheral blood mononuclear cells-derived NK cells from healthy donors in SARS-CoV-2-infected patients.

Moreover, an individual's monocytic-dendritic cells are pulsed with SARS-CoV-2 peptides and used to prime the same individual's $\mathrm{T}$ cells to produce SARS-CoV2-specific immune cells. These lymphocytic cells may be cryopreserved or infused into the vulnerable individual as prevention or treatment against COVID-19 [101]. DCs related to immunotherapy and cell-based vaccination, are the next cell-based therapy candidate for the treatment of COVID-19. In the USA, an immuno-oncology company designing personalized vaccines has recently conducted a clinical trial (NCT04386252) of a vaccine of autologous DCs loaded with antigens from SARS-CoV-2, with or without GM-CSF, to inhibit COVID-19 in adults [121, 122]. These DCs consist of peripheral blood monocyte-derived DCs collected from the blood samples of patients. However, there is no more information about the results of this trial. 


\section{Nutraceutical supplementation}

Some clinicians recommend the intake of vitamin and mineral supplements to combat respiratory viral infections. Recently, adjunctive therapies are frequently used in the inhibition and/or treatment of SARS-CoV-2 infection or its complications. Vitamins $C$ and D due to their immunomodulatory properties have received more attention to fighting against COVID-19 and it is estimated that these supplements may play a supportive role in infected patients and boost their immune system function [123].

An overview of systematic reviews of the association of vitamin $\mathrm{D}$, vitamin $\mathrm{C}$, zinc, and melatonin with inflammatory markers determined that using 50,000 IU/ month of vitamin D leads to regulation in C-reactive protein (CRP), an inflammatory marker [124]. An intake of 1-2 g/day of vitamin $C$ showed effectiveness in CRP and endothelial function, and a dose of $50 \mathrm{mg} /$ day of zinc nutraceutical demonstrated favorable changes in CRP. An amount of melatonin ranging from 5 to $25 \mathrm{mg} /$ day showed positive effects in CRP, TNF and IL-6 [124]. Hence, hospitalized SARS-CoV-2-infected patients indicated malnutrition and deficiencies in vitamin $\mathrm{C}, \mathrm{D}$, B12 selenium, iron, omega-3, and medium and longchain fatty acids [125], these findings may be useful in the inhibition and treatment of COVID-19 patients. Some clinical trials were designed to evaluate some of these supplements. A pilot study of high-dose vitamin C in critically ill COVID-19 patients showed statistically improvements in oxygenation from baseline to day 7 in the treatment group compared to the control group [126]. A randomized clinical trial recommended the using 5000 IU daily vitamin D3, even for a short period, as an adjuvant therapy for COVID-19 patients with suboptimal vitamin D status [127]. The results of their study indicated that the time to recovery for cough and gustatory sensory loss between mild to moderate COVID-19 patients with suboptimal vitamin D status decrease with 2 week intake of $5000 \mathrm{IU}$ vitamin D3 supplementation.

However, at present, there is inadequate data to recommend either for or against the intake of vitamins and mineral supplements for the inhibition or treatment of SARS-CoV-2-infected patients. More clinical trials are required to determine the complete role and implications of nutrition in the COVID-19 outbreak.

\section{Conclusion}

The SARS-CoV-2 pandemic is a "public health emergency of international concern". During this pandemic, many therapeutic strategies have been investigated for this deadly disease, including antivirals, anti-inflammatories, cell therapy, plasma therapy, monoclonal antibodies and intravenous immunoglobulin therapy. According to the results of several clinical studies, the drug repurposing strategy has confirmed its critical role in the rapid discovery of an efficient treatment option for COVID-19. Neutralizing mAb therapy is a promising and attractive approach for rapid prophylactic and treatment settings. Moreover, in conditions, where vaccines have less efficacy such as in immunocompromised people, young, elderly, and vaccine-hesitant individuals, mAb therapy may be an important option for SARS-CoV-2 infection. According to the findings of several clinical trials, cell therapy also improves COVID-19 patient recovery with safety and good immune tolerance. However, at present, there is no specific and approved option for treating SARS-CoV-2 infection yet and more studies are needed to determine the safety and efficacy of current treatment strategies. Although the COVID19 pandemic has brought great challenges, the continued efforts to combat the virus and the excellence and hard work of many researchers around the world give us hope of winning this battle in the near future.

\section{Acknowledgements \\ The authors gratefully acknowledge the support of the Shahid Beheshti Uni- versity of Medical Sciences and Urmia University of Medical Sciences. \\ Authors' contributions \\ MRT and YR the concept and design of the study; ZN, AJ, AG, FDP and MN gathered content and drafted the manuscript. ZN and AJ were major con- tributors in writing the manuscript. All authors read and approved the final manuscript.}

\section{Funding}

This research received no external funding.

Availability of data and materials

Not applicable.

\section{Declarations}

Ethics approval and consent to participate Not applicable.

\section{Consent for publication}

Not applicable.

\section{Competing interests}

The authors declare that they have no competing interests.

\section{Author details}

${ }^{1}$ Proteomics Research Center, Shahid Beheshti University of Medical Sciences, Tehran, Iran. ${ }^{2}$ Advanced Therapy Medicinal Product (ATMP) Department, Breast Cancer Research Center, Motamed Cancer Institute, ACECR, Tehran, Iran. ${ }^{3}$ Department of Clinical Biochemistry and Applied Cell Sciences, School of Medicine, Urmia University of Medical Sciences, Urmia, Iran. ${ }^{4}$ Department of Biochemistry, School of Medicine, Urmia University of Medical Sciences, Urmia, Iran. ${ }^{5}$ Proteomics Research Center, Faculty of Paramedical Sciences, Shahid Beheshti University of Medical Sciences, Tehran, Iran. ${ }^{6}$ Cellular and Molecular Research Center, Urmia University of Medical Sciences, Urmia, Iran. 
Received: 2 October 2021 Accepted: 23 December 2021

Published online: 13 January 2022

\section{References}

1. Hafeez A, Ahmad S, Siddqui SA, Ahmad M, Mishra S. A Review of COVID-19 (coronavirus disease-2019) diagnosis, treatments and prevention. Eurasian J Med Oncol. 2019. https://doi.org/10.14744/ejmo. 2020.90853

2. Barati F, Pouresmaieli M, Ekrami E, Asghari S, Ziarani FR, Mamoudifard M. Potential drugs and remedies for the treatment of COVID-19: a critical review. Biol Proced Online. 2020;22(1):1-17.

3. Mackenzie JS, Smith DW. COVID-19: a novel zoonotic disease caused by a coronavirus from China: what we know and what we don't. Microbiol Aust. 2020;41(1):45-50.

4. De Vito A, Fiore V, Princic E, Geremia N, Panu Napodano CM, Muredda $\mathrm{AA}$, et al. Predictors of infection, symptoms development, and mortality in people with SARS-CoV-2 living in retirement nursing homes. PLoS ONE. 2021;16(3): e0248009.

5. Vaira LA, Deiana G, Fois AG, Pirina P, Madeddu G, De Vito A, et al. Objective evaluation of anosmia and ageusia in COVID-19 patients: singlecenter experience on 72 cases. Head Neck. 2020;42(6):1252-8.

6. Geremia N, De Vito A, Gunnella S, Fiore V, Princic E, Napodano CP, et al. A case of vasculitis-like skin eruption associated with COVID-19. Infect Dis Clin Pract. 2020;28(6):e30-1.

7. Tufan A, Güler AA, Matucci-Cerinic M. COVID-19, immune system response, hyperinflammation and repurposing antirheumatic drugs. Turk J Med Sci. 2020;50(SI-1):620-32.

8. Hoffmann M, Kleine-Weber H, Schroeder S, Krüger N, Herrler T, Erichsen $\mathrm{S}$, et al. SARS-CoV-2 cell entry depends on ACE2 and TMPRSS2 and is blocked by a clinically proven protease inhibitor. Cell. 2020. https://doi. org/10.1016/..cell.2020.02.052

9. Khodadoost M, Niknam Z, Farahani M, Razzaghi M, Norouzinia M. Investigating the human protein-host protein interactome of SARSCoV-2 infection in the small intestine. Gastroenterol Hepatol Bed Bench. 2020;13(4):374.

10. Sadrabadi AE, Bereimipour A, Jalili A, Gholipurmalekabadi M, Farhadihosseinabadi B, Seifalian AM. The risk of pancreatic adenocarcinoma following SARS-CoV family infection. Sci Rep. 2021;11(1):1-13.

11. Farahani M, Niknam Z, Amirabad LM, Amiri-Dashatan N, Koushki M, Nemati M, et al. Molecular pathways involved in COVID-19 and potential pathway-based therapeutic targets. Biomed Pharmacother. 2021. https://doi.org/10.1016/j.biopha.2021.112420.

12. Shi Y, Wang Y, Shao C, Huang J, Gan J, Huang X, et al. COVID-1 9 infection: the perspectives on immune responses. Cell Death Differ. 2020 https://doi.org/10.1038/s41418-020-0530-3.

13. Gavriatopoulou M, Ntanasis-Stathopoulos I, Korompoki E, Fotiou D, Migkou M, Tzanninis I-G, et al. Emerging treatment strategies for COVID-19 infection. Clin Exp Med. 2020. https://doi.org/10.1007/ s10238-020-00671-y.

14. Senanayake SL. Drug repurposing strategies for COVID. Future Drug Discov. 2020. https://doi.org/10.4155/fdd-2020-0010.

15. Molavi Z, Razi S, Mirmotalebisohi SA, Adibi A, Sameni M, Karami F, et al. Identification of FDA approved drugs against SARS-CoV-2 RNA dependent RNA polymerase (RdRp) and 3-chymotrypsin-like protease (3CLpro), drug repurposing approach. Biomed Pharmacother. 2021. https://doi. org/10.1016/j.biopha.2021.111544.

16. Williamson BN, Feldmann F, Schwarz B, Meade-White K, Porter DP, Schulz J, et al. Clinical benefit of remdesivir in rhesus macaques infected with SARS-CoV-2. Nature. 2020:585(7824):273-6.

17. Grein J, Ohmagari N, Shin D, Diaz G, Asperges E, Castagna A, et al. Compassionate use of remdesivir for patients with severe Covid-19. N Engl J Med. 2020;382(24):2327-36.

18. Wang Y, Zhang D, Du G, Du R, Zhao J, Jin Y, et al. Remdesivir in adults with severe COVID-19: a randomised, double-blind, placebo-controlled, multicentre trial. Lancet. 2020. https://doi.org/10.1016/S0140-6736(20) 31022-9.

19. Singh S, Khera D, Chugh A, Khera PS, Chugh VK. Efficacy and safety of remdesivir in COVID-19 caused by SARS-CoV-2: a systematic review and meta-analysis. BMJ Open. 2021;11(6): e048416.
20. Kaka AS, MacDonald R, Greer N, Vela K, Duan-Porter W, Obley A, et al. Major update: remdesivir for adults with COVID-19: a living systematic review and meta-analysis for the American College of Physicians Practice Points. Ann Intern Med. 2021;174(5):663-72.

21. Al-Abdouh A, Bizanti A, Barbarawi M, Jabri A, Kumar A, Fashanu OE, et al. Remdesivir for the treatment of COVID-19: a systematic review and meta-analysis of randomized controlled trials. Contemp Clin Trials. 2021. https://doi.org/10.1016/j.cct.2021.106272.

22. Kalil AC, Patterson TF, Mehta AK, Tomashek KM, Wolfe CR, Ghazaryan $V_{\text {, }}$ et al. Baricitinib plus remdesivir for hospitalized adults with Covid-19. N Engl J Med. 2021;384(9):795-807.

23. Nitulescu GM, Paunescu H, Moschos SA, Petrakis D, Nitulescu G, Ion GND, et al. Comprehensive analysis of drugs to treat SARS-CoV-2 infection: mechanistic insights into current COVID-19 therapies. Int J Mol Med. 2020. https://doi.org/10.3892/ijmm.2020.4608.

24. Dehelean CA, Lazureanu V, Coricovac D, Mioc M, Oancea R, Marcovici I, et al. SARS-CoV-2: repurposed drugs and novel therapeutic approaches-insights into chemical structure-biological activity and toxicological screening. J Clin Med. 2020;9(7):2084.

25. Soy M, Keser G, Atagündüz P, Tabak F, Atagündüz I, Kayhan S. Cytokine storm in COVID-19: pathogenesis and overview of anti-inflammatory agents used in treatment. Clin Rheumatol. 2020. https://doi.org/10. 1007/s10067-020-05190-5.

26. Chen C-x, Wang J-j, Li H, Yuan L-t, Gale RP, Liang Y. JAK-inhibitors for coronavirus disease-2019 (COVID-19): a meta-analysis. Leukemia. 2021. https://doi.org/10.1038/s41375-021-01266-6.

27. Magro G. COVID-19: review on latest available drugs and therapies against SARS-CoV-2. Coagulation and inflammation cross-talking. Virus Res. 2020. https://doi.org/10.1016/j.virusres.2020.198070.

28. Ma S, Xu C, Liu S, Sun X, Li R, Mao M, et al. Efficacy and safety of systematic corticosteroids among severe COVID-19 patients: a systematic review and meta-analysis of randomized controlled trials. Signal Transduct Target Ther. 2021;6(1):1-7.

29. Sterne JA, Murthy S, Diaz JV, Slutsky AS, Villar J, Angus DC, et al. Association between administration of systemic corticosteroids and mortality among critically ill patients with COVID-19: a meta-analysis. JAMA. 2020;324(13):1330-41.

30. Pons S, Fodil S, Azoulay E, Zafrani L. The vascular endothelium: the cornerstone of organ dysfunction in severe SARS-CoV-2 infection. Crit Care. 2020;24(1):1-8.

31. Iba T, Connors JM, Levy JH. The coagulopathy, endotheliopathy, and vasculitis of COVID-19. Inflamm Res. 2020. https://doi.org/10.1007/ s00011-020-01401-6.

32. REMAP-CAP, ACTIV-4a, ATTACC Investigators. Therapeutic anticoagulation with heparin in critically ill patients with Covid-19. N Engl J Med. 2021:385(9):777-89.

33. Mazloomzadeh S, Khaleghparast S, Ghadrdoost B, Mousavizadeh M, Baay MR, Noohi F, et al. Effect of intermediate-dose vs standard-dose prophylactic anticoagulation on thrombotic events, extracorporeal membrane oxygenation treatment, or mortality among patients with COVID-19 admitted to the intensive care unit: the INSPIRATION randomized clinical trial. JAMA. 2021;325(16):1620-30.

34. Hassanipour S, Arab-Zozani M, Amani B, Heidarzad F, Fathalipour M, Martinez-de-Hoyo R. The efficacy and safety of Favipiravir in treatment of COVID-19: a systematic review and meta-analysis of clinical trials. Sci Rep. 2021;11(1):1-11.

35. Wei FF, Moradkhani A, Hemmati Hezaveh H, Miraboutalebi SA, Salehi L. Evaluating the treatment with favipiravir in patients infected by COVID19: a systematic review and meta-analysis. Int J Sci Res Dent Med Sci. 2020;2(3):87-91.

36. Manabe T, Kambayashi D, Akatsu H, Kudo K. Favipiravir for the treatment of patients with COVID-19: a systematic review and meta-analysis. BMC Infect Dis. 2021;21(1):1-13.

37. Zein AFMZ, Sulistiyana CS, Raffaello WM, Wibowo A, Pranata R. Sofosbuvir with daclatasvir and the outcomes of patients with COVID-19: a systematic review and meta-analysis with GRADE assessment. Postgrad Med J. 2021. https://doi.org/10.1136/postgradmedj-2021-140287.

38. Chan H-T, Chao C-M, Lai C-C. Sofosbuvir/daclatasvir in the treatment of COVID-19 infection: a meta-analysis. J Infect. 2021;82(4):e34-5. 
39. Fischer WA, Eron JJ, Holman W, Cohen MS, Fang L, Szewczyk LJ, et al. Molnupiravir, an oral antiviral treatment for COVID-19. medRxiv. 2021. https://doi.org/10.1101/2021.06.17.21258639.

40. Zhang Z, Wang S, Tu X, Peng X, Huang Y, Wang L, et al. A comparative study on the time to achieve negative nucleic acid testing and hospital stays between danoprevir and lopinavir/ritonavir in the treatment of patients with COVID-19. J Med Virol. 2020;92(11):2631-6.

41. Fhatonah N, Dewianti ZP, Rusdiana N. The effectiveness of remdesivir versus ruxolitinib as Covid-19 supportive management: systematic review, meta-analysis. 4th International Conference on Sustainable Innovation 2020-Health Science and Nursing (ICoSIHSN 2020); 2021. Atlantis Press.

42. Cao $Y$, Wei J, Zou L, Jiang $T$, Wang $G$, Chen $L$, et al. Ruxolitinib in treatment of severe coronavirus disease 2019 (COVID-19): a multicenter, single-blind, randomized controlled trial. J Allergy Clin Immunol. 2020;146(1):137-46. e3.

43. Guimarães PO, Quirk D, Furtado RH, Maia LN, Saraiva JF, Antunes MO, et al. Tofacitinib in patients hospitalized with Covid-19 pneumonia. N Engl J Med. 2021. https://doi.org/10.1056/NEJMoa2101643.

44. Aman J, Duijvelaar E, Botros L, Kianzad A, Schippers JR, Smeele PJ, et al. Imatinib in patients with severe COVID-19: a randomised, double-blind, placebo-controlled, clinical trial. Lancet Respir Med. 2021. https://doi. org/10.1016/S2213-2600(21)00237-X.

45. Lenze EJ, Mattar C, Zorumski CF, Stevens A, Schweiger J, Nicol GE, et al. Fluvoxamine vs placebo and clinical deterioration in outpatients with symptomatic COVID-19: a randomized clinical trial. JAMA. 2020;324(22):2292-300

46. Pinzón MA, Ortiz S, Holguín H, Betancur JF, Cardona Arango D, Laniado $\mathrm{H}$, et al. Dexamethasone vs methylprednisolone high dose for Covid-19 pneumonia. PLoS ONE. 2021;16(5): e0252057.

47. Edalatifard M, Akhtari M, Salehi M, Naderi Z, Jamshidi A, Mostafaei S, et al. Intravenous methylprednisolone pulse as a treatment for hospitalised severe COVID-19 patients: results from a randomised controlled clinical trial. Eur Respir J. 2020. https://doi.org/10.1183/13993003. 02808-2020.

48. Ranjbar K, Moghadami M, Mirahmadizadeh A, Fallahi MJ, Khaloo V, Shahriarirad R, et al. Methylprednisolone or dexamethasone, which one is superior corticosteroid in the treatment of hospitalized COVID-19 patients: a triple-blinded randomized controlled trial. BMC Infect Dis. 2021:21(1):1-8.

49. Ramakrishnan S, Nicolau DV Jr, Langford B, Mahdi M, Jeffers H, Mwasuku C, et al. Inhaled budesonide in the treatment of early COVID-19 (STOIC): a phase 2, open-label, randomised controlled trial. Lancet Respir Med. 2021. https://doi.org/10.1016/S2213-2600(21)00160-0.

50. Yu L-M, Bafadhel M, Dorward J, Hayward G, Saville BR, Gbinigie O, et al. Inhaled budesonide for COVID-19 in people at high risk of complications in the community in the UK (PRINCIPLE): a randomised, controlled, open-label, adaptive platform trial. Lancet. 2021;398(10303):843-55.

51. Lin $Y, W u ~ F, ~ X i e ~ Z$, Song $X$, Zhu Q, Wei J, et al. Clinical study of artesunate in the treatment of coronavirus disease 2019. Zhonghua wei zhong bing ji jiu yi xue. 2020;32(4):417-20.

52. Nakhlband A, Fakhari A, Azizi H. Interferon-beta offers promising avenues to COVID-19 treatment: a systematic review and meta-analysis of clinical trial studies. Naunyn-schmiedeberg's Arch Pharmacol. 2021. https://doi.org/10.1007/s00210-021-02061-x.

53. Walz L, Cohen AJ, Rebaza AP, Vanchieri J, Slade MD, Cruz CSD, et al. Janus kinase-inhibitor and type I interferon ability to produce favorable clinical outcomes in COVID-19 patients: a systematic review and metaanalysis. medRxiv. 2020. https://doi.org/10.1101/2020.08.10.20172189.

54. Duarte M, Pelorosso FG, Nicolosi L, Salgado MV, Vetulli H, Aquieri A, et al. Telmisartan for treatment of Covid-19 patients: an open randomized clinical trial. Preliminary report. medRxiv. 2020. https://doi.org/10.1101/ 2020.08.04.20167205.

55. Kow CS, Ming LC, Hasan SS. Renin-angiotensin system inhibitor use and the risk of mortality in hospitalized patients with COVID-19: a metaanalysis of randomized controlled trials. Hypertens Res. 2021. https:// doi.org/10.1038/s41440-021-00670-w.

56. Blum VF, Cimerman S, Hunter JR, Tierno P, Lacerda A, Soeiro A, et al. Nitazoxanide superiority to placebo to treat moderate COVID-19-a Pilot prove of concept randomized double-blind clinical trial. EClinicalMedicine. 2021;37: 100981.
57. Rocco PR, Silva PL, Cruz FF, Melo-Junior MAC, Tierno PF, Moura MA, et al. Early use of nitazoxanide in mild Covid-19 disease: randomised, placebo-controlled trial. Eur Respir J. 2021. https://doi.org/10.1183/ 13993003.03725-2020.

58. Abdulamir AS, Gorial Fl, Saaedi SJ, Maulood MF, Hashim HA. Effectiveness and safety of niclosamaide as add-on therapy to the standard of care measures in COVID-19 management: randomized controlled clinical trial. medRxiv. 2021. https://doi.org/10.1101/2021.06.10.21258709.

59. Ansarin $K$, Tolouian $R$, Ardalan $M$, Taghizadieh A, Varshochi M, Teimouri $\mathrm{S}$, et al. Effect of bromhexine on clinical outcomes and mortality in COVID-19 patients: a randomized clinical trial. Biolmpacts. 2020;10(4):209.

60. Mikhaylov EN, Lyubimtseva TA, Vakhrushev AD, Stepanov D, Lebedev DS, Vasilieva EY, et al. Bromhexine hydrochloride prophylaxis of COVID19 for medical personnel: a randomized open-label study. medRxiv. 2021. https://doi.org/10.1101/2021.03.03.21252855.

61. Toma A, Darwish C, Taylor M, Harlacher J, Darwish R. The use of dornase alfa in the management of COVID-19-associated adult respiratory distress syndrome. Crit Care Res Pract. 2021. https://doi.org/10.1155/2021/ 8881115.

62. Weber AG, Chau AS, Egeblad M, Barnes BJ, Janowitz T. Nebulized in-line endotracheal dornase alfa and albuterol administered to mechanically ventilated COVID-19 patients: a case series. Mol Med. 2020;26(1):1-7.

63. Uusalo $\mathrm{P}$, Valtonen M, Järvisalo MJ. Hemodynamic and respiratory effects of dexmedetomidine sedation in critically III Covid-19 patients. A retrospective cohort study. Acta Anaesthesiol Scand. 2021. https://doi. org/10.1111/aas.13970.

64. Ju T, Lee CC, Chen W-c, Lin H-T. Use of dexmedetomidine in critically ill patients receiving noninvasive ventilation: a meta-analysis of randomized controlled trials. Chest. 2020;158(4):A577.

65. Hoertel N, Sánchez-Rico M, Vernet R, Beeker N, Jannot A-S, Neuraz $A$, et al. Association between antidepressant use and reduced risk of intubation or death in hospitalized patients with COVID-19: results from an observational study. Mol Psychiatry. 2021. https://doi.org/10.1038/ s41380-021-01021-4.

66. Rojas M, Rodríguez Y, Monsalve DM, Acosta-Ampudia Y, Camacho B, Gallo JE, et al. Convalescent plasma in Covid-19: possible mechanisms of action. Autoimmun Rev. 2020. https://doi.org/10.1016/j.autrev.2020. 102554.

67. Van Erp EA, Luytjes W, Ferwerda G, Van Kasteren PB. Fc-mediated antibody effector functions during respiratory syncytial virus infection and disease. Front Immunol. 2019;10:548.

68. Gunn BM, Yu W-H, Karim MM, Brannan JM, Herbert AS, Wec AZ, et al. A role for Fc function in therapeutic monoclonal antibody-mediated protection against Ebola virus. Cell Host Microbe. 2018;24(2):221-33. e5.

69. Garraud O, Heshmati F, Pozzetto B, Lefrere F, Girot R, Saillol A, et al. Plasma therapy against infectious pathogens, as of yesterday, today and tomorrow. Transfus Clin Biol. 2016;23(1):39-44.

70. Klassen SA, Senefeld JW, Johnson PW, Carter RE, Wiggins CC, Shoham S, et al. The effect of convalescent plasma therapy on COVID-19 patient mortality: systematic review and meta-analysis. Mayo Clin Proc. 2021. https://doi.org/10.1016/j.mayocp.2021.02.008.

71. Prasad M, Seth T, Elavarasi A. Efficacy and safety of convalescent plasma for COVID-19: a systematic review and meta-analysis. Indian J Hematol Blood Transfus. 2021. https://doi.org/10.1007/s12288-021-01417-w.

72. Joyner MJ, Senefeld JW, Klassen SA, Mills JR, Johnson PW, Theel ES, et al. Effect of convalescent plasma on mortality among hospitalized patients with COVID-19: initial three-month experience. medRxiv. 2020. https://doi.org/10.1101/2020.08.12.20169359.

73. Cheraghali AM, Abolghasemi H, Eshghi P. Management of COVID-19 virus infection by convalescent plasma. Iran J Allergy Asthma Immunol. 2020. https://doi.org/10.18502/ijaai.v19i(s1.r1).2847.

74. Shanmugaraj B, Siriwattananon K, Wangkanont K, Phoolcharoen W. Perspectives on monoclonal antibody therapy as potential therapeutic intervention for coronavirus disease-19 (COVID-19). Asian Pac J Allergy Immunol. 2020;38(1):10-8.

75. Jafari A, Mostafa R-T, Karami S, Yazdani M, Zali H, Jafari Z. Cancer care management during the COVID-19 pandemic. Risk Manag Healthc Policy. 2020;13:1711-21. 
76. Hussen J, Kandeel M, Hemida MG, Al-Mubarak Al. Antibodybased immunotherapeutic strategies for COVID-19. Pathogens. 2020;9(11):917.

77. Liu C, Zhou Q, Li Y, Garner LV, Watkins SP, Carter LJ, et al. Research and development on therapeutic agents and vaccines for COVID-19 and related human coronavirus diseases. ACS Cent Sci. 2020. https://doi. org/10.1021/acscentsci.0c00272.

78. Esmaeilzadeh A, Elahi R. Immunobiology and immunotherapy of COVID-19: a clinically updated overview. J Cell Physiol. 2020. https:// doi.org/10.1002/jcp.30076.

79. Yang L, Xie X, Tu Z, Fu J, Xu D, Zhou Y. The signal pathways and treatment of cytokine storm in COVID-19. Signal Transduct Target Ther. 2021:6(1):1-20.

80. Liu B, Li M, Zhou Z, Guan X, Xiang Y. Can we use interleukin-6 (IL-6) blockade for coronavirus disease 2019 (COVID-19)-induced cytokine release syndrome (CRS)? J Autoimmun. 2020. https://doi.org/10. 1016/j.jaut.2020.102452.

81. de Andrade Santos I, Grosche VR, Bergamini FRG, Sabino-Silva R, Jardim ACG. Antivirals against coronaviruses: candidate drugs for SARS-coV-2 treatment? Front Microbiol. 2020;11:1818.

82. Khan FA, Stewart I, Fabbri L, Moss S, Robinson K, Smyth AR, et al. Systematic review and meta-analysis of anakinra, sarilumab, siltuximab and tocilizumab for COVID-19. Thorax. 2021. https://doi.org/10.1136/ thoraxjnl-2020-215266.

83. van der Ven AJ, Netea MG, van der Meer JW, de Mast Q. Ebola virus disease has features of hemophagocytic lymphohistiocytosis syndrome. Front Med. 2015;2:4

84. Kyriazopoulou E, Huet T, Cavalli G, Gori A, Kyprianou M, Pickkers P, et al. Effect of anakinra on mortality in patients with COVID-19: a systematic review and patient-level meta-analysis. Lancet Rheumatol. 2021. https://doi.org/10.1016/S2665-9913(21)00216-2.

85. Barkas F, Ntekouan SF, Kosmidou M, Liberopoulos E, Liontos A, Milionis $\mathrm{H}$. Anakinra in hospitalized non-intubated patients with coronavirus disease 2019: a systematic review and meta-analysis. Rheumatology. 2021. https://doi.org/10.1093/rheumatology/keab4 47.

86. Avdeev SN, Trushenko NV, Tsareva NA, Yaroshetskiy Al, Merzhoeva ZM, Nuralieva GS, et al. Anti-IL-17 monoclonal antibodies in hospitalized patients with severe COVID-19: a pilot study. Cytokine. 2021;146: 155627.

87. Bonaventura A, Vecchié A, Wang TS, Lee E, Cremer PC, Carey B, et al. Targeting GM-CSF in COVID-19 pneumonia: rationale and strategies. Front Immunol. 2020;11:1625.

88. Guan J-T, Wang W-J, Jin D, Mou X-Y, Lei S-S, Xu Z-H. A meta-analysis of granulocyte-macrophage colony-stimulating factor (GM-CSF) antibody treatment for COVID-19 patients. Ther Adv Chronic Dis. 2021;12: 20406223211039699

89. Robson B. COVID-19 Coronavirus spike protein analysis for synthetic vaccines, a peptidomimetic antagonist, and therapeutic drugs, and analysis of a proposed achilles' heel conserved region to minimize probability of escape mutations and drug resistance. Comput Biol Med. 2020. https://doi.org/10.1016/j.compbiomed.2020.103749.

90. Prompetchara E, Ketloy C, Palaga T. Immune responses in COVID-19 and potential vaccines: lessons learned from SARS and MERS epidemic. Asian Pac J Allergy Immunol. 2020;38(1):1-9.

91. Kumar S, Chandele A, Sharma A. Current status of therapeutic monoclonal antibodies against SARS-CoV-2. PLoS Pathog. 2021;17(9): e1009885.

92. Dougan M, Nirula A, Azizad M, Mocherla B, Gottlieb RL, Chen P, Hebert C, Perry R, Boscia J, Heller B, Morris J. Bamlanivimab plus etesevimab in mild or moderate Covid-19. New England J Med. 2021;385(15):1382-92. https://doi.org/10.1056/NEJMoa2102685.

93. Food and Drug Administration. Fact sheet for healthcare providers: emergency use authorization (EUA) of bamlanivimab and etesevimab. 2021. https://www.fda.gov/media/145802/download. Accessed 17 Feb 2021

94. Cohen MS, Nirula A, Mulligan MJ, et al. Effect of bamlanivimab vs placebo on incidence of COVID-19 among residents and staff of skilled nursing and assisted living facilities: a randomized clinical trial. JAMA. 2021:326(1):46-55.

95. O'Brien MP, Neto EF, Musser BJ, Isa F, Chan KC, Sarkar N, Bar KJ, Barnabas RV, Barouch DH,Cohen MS, Hurt CB. Subcutaneous REGEN-COV antibody combination for Covid-19 prevention. medRxiv. 2021. https:// doi: 10.1056/NEJMoa2109682.

96. Taylor PC, Adams AC, Hufford MM, de la Torre I, Winthrop K, Gottlieb RL. Neutralizing monoclonal antibodies for treatment of COVID-19. Nat Rev Immunol. 2021. https://doi.org/10.1038/s41577-021-00542-x.

97. Sakoulas G, Geriak M, Kullar R, Greenwood KL, Habib M, Vyas A, et al. Intravenous immunoglobulin plus methylprednisolone mitigate respiratory morbidity in coronavirus disease 2019. Crit Care Explor. 2020. https://doi.org/10.1097/CCE.0000000000000280.

98. Galeotti C, Kaveri SV, Bayry J. Intravenous immunoglobulin immunotherapy for coronavirus disease-19 (COVID-19). Clin Transl Immunol. 2020;9(10): e1198.

99. Cheng MH, Zhang S, Porritt RA, Rivas MN, Paschold L, Willscher E, et al. Superantigenic character of an insert unique to SARS-CoV-2 spike supported by skewed TCR repertoire in patients with hyperinflammation. Proc Natl Acad Sci. 2020;117(41):25254-62.

100. Xiang H-r, Cheng X, Li Y, Luo W-W, Zhang Q-z, Peng W-x. Efficacy of IVIG (intravenous immunoglobulin) for corona virus disease 2019 (COVID19): a meta-analysis. Int Immunopharmacol. 2019;2021(96): 107732.

101. Golchin A. Cell-based therapy for severe COVID-19 patients: clinical trials and cost-utility. Stem Cell Rev Rep. 2020. https://doi.org/10.1007/ s12015-020-10046-1.

102. Golchin A, Seyedjafari E, Ardeshirylajimi A. Mesenchymal stem cell therapy for COVID-19: present or future. Stem Cell Rev Rep. 2020. https://doi.org/10.1007/s12015-020-09973-w.

103. Golchin A, Rekabgardan M, Taheri RA, Nourani MR. Promotion of cellbased therapy: special focus on the cooperation of mesenchymal stem cell therapy and gene therapy for clinical trial studies. Cell Biol Transl Med. 2018:4:103-18.

104. Golchin A, Farahany TZ. Biological products: cellular therapy and FDA approved products. Stem Cell Rev Rep. 2019;15(2):166-75.

105. Golchin A, Farahany TZ, Khojasteh A, Soleimanifar F, Ardeshirylajimi A. The clinical trials of mesenchymal stem cell therapy in skin diseases: an update and concise review. Curr Stem Cell Res Ther. 2019;14(1):22-33.

106. Razi S, Molavi Z, Mirmotalebisohi SA, Niknam Z, Sameni M, Niazi V, et al. Mesenchymal stem cells in the treatment of new coronavirus pandemic: a novel promising therapeutic approach. Adv Pharm Bull. 2021. https://doi.org/10.34172/apb.2022.023.

107. Lukomska B, Stanaszek L, Zuba-Surma E, Legosz P, Sarzynska S, Drela K. Challenges and controversies in human mesenchymal stem cell therapy. Stem Cells Int. 2019. https://doi.org/10.1155/2019/9628536.

108. Shetty AK. Mesenchymal stem cell infusion shows promise for combating coronavirus (COVID-19)-induced pneumonia. Aging Dis. 2020:11(2):462

109. Kavianpour M, Saleh M, Verdi J. The role of mesenchymal stromal cells in immune modulation of COVID-19: focus on cytokine storm. Stem Cell Res Ther. 2020;11(1):1-19.

110. Wang J, Shi P, Chen D, Wang S, Wang P, Feng X, et al. Research status of the safety and efficacy of mesenchymal stem cells in the treatment of COVID-19-related pneumonia: a systematic review and meta-analysis. Stem Cells Dev. 2021. https://doi.org/10.1089/scd.2021.0179.

111. Lanzoni G, Linetsky E, Correa D, Messinger Cayetano S, Alvarez RA, Kouroupis D, et al. Umbilical cord mesenchymal stem cells for COVID19 acute respiratory distress syndrome: a double-blind, phase 1/2a, randomized controlled trial. Stem Cells Transl Med. 2021;10(5):660-73.

112. Shi L, Huang $H$, Lu X, Yan X, Jiang $X$, Xu R, et al. Effect of human umbilical cord-derived mesenchymal stem cells on lung damage in severe COVID-19 patients: a randomized, double-blind, placebo-controlled phase 2 trial. Signal Transduct Target Ther. 2021;6(1):1-9.

113. Meng F, Xu R, Wang S, Xu Z, Zhang C, Li Y, et al. Human umbilical cordderived mesenchymal stem cell therapy in patients with COVID-19: a phase 1 clinical trial. Signal Transduct Target Ther. 2020;5(1):172.

114. Shu L, Niu C, Li R, Huang T, Wang Y, Huang M, et al. Treatment of severe COVID-19 with human umbilical cord mesenchymal stem cells. Stem Cell Res Ther. 2020;11(1):1-11.

115. Hashemian S-MR, Aliannejad R, Zarrabi M, Soleimani M, Vosough M, Hosseini S-E, et al. Mesenchymal stem cells derived from perinatal tissues for treatment of critically ill COVID-19-induced ARDS patients: a case series. Stem Cell Res Ther. 2021;12(1):1-12. 
116. Tang L, Jiang Y, Zhu M, Chen L, Zhou X, Zhou C, et al. Clinical study using mesenchymal stem cells for the treatment of patients with severe COVID-19. Front Med. 2020;14(5):664-73.

117. Xu X, Jiang W, Chen L, Xu Z, Zhang Q, Zhu M, et al. Evaluation of the safety and efficacy of using human menstrual blood-derived mesenchymal stromal cells in treating severe and critically ill COVID-19 patients: an exploratory clinical trial. Clin Transl Med. 2021;11(2): e297.

118. Sánchez-Guijo F, García-Arranz M, López-Parra M, Monedero P, MataMartínez C, Santos A, et al. Adipose-derived mesenchymal stromal cells for the treatment of patients with severe SARS-CoV-2 pneumonia requiring mechanical ventilation. A proof of concept study. EClinicalMedicine. 2020;25: 100454.

119. Leng Z, Zhu R, Hou W, Feng Y, Yang Y, Han Q, et al. Transplantation of ACE2-mesenchymal stem cells improves the outcome of patients with COVID-19 pneumonia. Aging Dis. 2020;11(2):216.

120. Market M, Angka L, Martel AB, Bastin D, Olanubi O, Tennakoon G, et al. Flattening the COVID-19 curve with natural killer cell based immunotherapies. Front Immunol. 2020. https://doi.org/10.3389/fimmu.2020. 01512.

121. Korang SK, Juul S, Nielsen EE, Feinberg J, Siddiqui F, Ong G, et al. Vaccines to prevent COVID-19: a protocol for a living systematic review with network meta-analysis including individual patient data (The LIVING VACCINE Project). Syst Rev. 2020;9(1):1-15.

122. Li Y-D, Chi W-Y, Su J-H, Ferrall L, Hung C-F, Wu T-C. Coronavirus vaccine development: from SARS and MERS to COVID-19. J Biomed Sci. 2020;27(1):1-23.

123. Darbar S, Saha S, Agarwal S. Immunomodulatory role of vitamin C, D and $E$ to fight against COVID-19 infection through boosting immunity: a review. Parana J Sci Educ. 2021;7(1):10-8.

124. Corrao S, Mallaci Bocchio R, Lo Monaco M, Natoli G, Cavezzi A, Troiani $E$, et al. Does evidence exist to blunt inflammatory response by nutraceutical supplementation during COVID-19 pandemic? An overview of systematic reviews of vitamin D, vitamin C, Melatonin, and zinc. Nutrients. 2021;13(4):1261.

125. Clemente-Suárez VJ, Ramos-Campo DJ, Mielgo-Ayuso J, Dalamitros AA, Nikolaidis PA, Hormeño-Holgado A, et al. Nutrition in the actual COVID19 pandemic. A narrative review. Nutrients. 2021;13(6):1924.

126. Zhang J, Rao X, Li Y, Zhu Y, Liu F, Guo G, et al. Pilot trial of high-dose vitamin C in critically ill COVID-19 patients. Ann Intensive Care. 2021;11(1):1-12.

127. Sabico S, Enani MA, Sheshah E, Aljohani NJ, Aldisi DA, Alotaibi NH, et al. Effects of a 2-Week 5000 IU versus 1000 IU Vitamin D3 supplementation on recovery of symptoms in patients with mild to moderate Covid-19: a randomized clinical trial. Nutrients. 2021;13(7):2170.

128. Basiri A, Mansouri F, Azari A, Ranjbarvan P, Zarein F, Heidari A, et al. Stem cell therapy potency in personalizing severe COVID-19 treatment. Stem Cell Rev Rep. 2021. https://doi.org/10.1007/s12015-020-10110-w.

\section{Publisher's Note}

Springer Nature remains neutral with regard to jurisdictional claims in published maps and institutional affiliations.

Ready to submit your research? Choose BMC and benefit from:

- fast, convenient online submission

- thorough peer review by experienced researchers in your field

- rapid publication on acceptance

- support for research data, including large and complex data types

- gold Open Access which fosters wider collaboration and increased citations

- maximum visibility for your research: over 100M website views per year

At BMC, research is always in progress.

Learn more biomedcentral.com/submissions 